Exploring Political Tolerance with Adolescents

by Patricia G. Avery,

Karen Bird, Sandra Johnstone,

John L. Sullivan, and Kristina Thalhammer

CURA RESOURCE COLLECTION

Center for Urban and Regional Afifairs University of Minnesota 330 Humphrey Center 
A publication of the Center for Urban and Regional Affairs, 330 Hubert H. Humphrey Center, 301 19th Avenue S., Minneapolis, MN 55455.

The content of this report is the responsibility of the authors and is not necessarily endorsed by CURA.

1993

Publication No. CURA 93-2

by Patricia G. Avery

Department of Curriculum and Instruction

University of Minnesota

Karen Bird, Sandra Johnstone, John L. Sullivan, and

Kristina Thalhammer

Department of Political Science

University of Minnesota 


\section{TABLE OF CONTENTS}

Abstract 1

Do All of the People Have All of the Rights All of the Time?

Related Research

$\begin{array}{ll}\text { Political Tolerance } & 5\end{array}$

$\begin{array}{ll}\text { A Focus on Adolescence } & 6\end{array}$

$\begin{array}{ll}\text { The Civics Curriculum and Political Tolerance } & 7\end{array}$

$\begin{array}{ll}\text { Method } & 11\end{array}$

Tolerance for Diversity of Belief: A Curriculum 11

The Students, the Schools, and the Design 12

$\begin{array}{ll}\text { Measures } & 13\end{array}$

$\begin{array}{ll}\text { Results } & 17\end{array}$

The Curriculum and Increases in Political Tolerance 17

The Curriculum and Threat Perceptions 19

$\begin{array}{ll}\text { A Multivariate Analysis of Political Tolerance } & 20\end{array}$

Students' Explanations for Tolerant/Intolerant Responses 22

$\begin{array}{ll}\text { Discussion and Implications } & 27\end{array}$

$\begin{array}{lr}\text { Appendix } & 29\end{array}$

References $\quad 31$

-iii- 



\title{
EXPLORING POLITICAL TOLERANCE WITH ADOLESCENTS ${ }^{1}$
}

\begin{abstract}
Most research on political socialization has suggested that the traditional formal civics curriculum has limited impact on students' civic attitudes (Ehman, 1980). Political tolerance-the willingness to acknowledge the civil liberties of those with whom one disagrees - is no exception. Although civics courses do emphasize abstract democratic norms such as freedom of speech, they tend not to link them directly with everyday political situations in which these norms can be applied. We have developed and tested a curriculum that encourages students to explore the linkages among democratic values and legal principles, and their application to unpopular groups in our society. Our data suggest that increases in political tolerance are due to a greater awareness of individual rights; decreases in tolerance may be attributed to heightened concern for public safety.
\end{abstract}

1 The authors wish to acknowledge the comments of Marcus Flathman, the cooperation and assistance of several public school teachers, and the financial and other support provided by the Center for Applied Research and Educational Improvement (CAREI) and the Center for Urban and Regional Affairs (CURA), both of the University of Minnesota. 



\title{
DO ALL OF THE PEOPLE HAVE ALL OF THE RIGHTS
}

\section{ALL OF THE TIME?}

\begin{abstract}
Clearly the American civil liberties record has deep flaws in it, especially in social and racial justice and toleration of radical political expression, and clearly the record is not as pristine as American ideals are. Yet it must also be remembered that the record would probably not be as good as it is if American ideals were not so high, for they act as a constant standard and constant challenge. Further, the American record, it should be reiterated, compares favorably with the vast majority of countries in the world today. (Goldstein, 1987, pp. 451-452)
\end{abstract}

There is a deep and abiding paradox in the American civil liberties record. On the one hand, we enjoy some of the widest and deepest legal protections for our civil rights and liberties accorded citizens anywhere in the world. On the other hand, we have often indulged in profound abrogations of these rights and liberties for substantial segments of our society, including, among others, the internment of Japanese-Americans during World War II and the well-documented abuses of the McCarthy era.

Surveys of the political attitudes and beliefs of American adults provide insight into our record. Americans profess overwhelming support for democratic principles (McClosky \& Zaller, 1984; Sullivan, Piereson, \& Marcus, 1982). For example, when asked if they believe in free speech for everyone, about 90 percent of Americans will say yes (McClosky \& Brill, 1983). Yet, studies show dishearteningly little support for the impartial application of these principles to groups that express unpopular ideas (Gibson, 1988, 1989; McClosky \& Brill, 1983; Sullivan, Piereson, \& Marcus, 1982). When asked about a more specific situation, such as the Ku Klux Klan appearing on public television or the Communists marching in their neighborhood, less than 30 percent will support the rights of free speech and assembly (McClosky \& Brill, 1983).

One possible explanation for the disparity between support for civil liberties in the abstract and their application in concrete situations is that many people simply do not make the connection between the two. When asked whether the American Nazi party should be given access to public television, for example, many people may not even consider the value of free speech; rather, they tend to focus exclusively on their abhorrence of the group's political views. Indeed, many citizens lack an understanding of how the abstract principles of freedom of speech and minority rights are embedded in a system of legal protections and rights (Sullivan, Piereson \& Marcus, 1982). Those interested in political education have suggested that traditional civics curricula perpetuate this disjuncture by failing to analyze rights within specific contexts (Corbett, 1991; Zellman, 1975).

After a brief overview of the research related to political tolerance, we argue that adolescence is an ideal period for the exploration of issues related to individual rights and the public good. We review literature which suggests that traditional civics curricula often fail to meet this challenge. Results are presented from a study designed to explore the potential of a civics curriculum in developing a willingness to acknowledge the civil liberties of disliked or unpopular groups. Finally, we discuss the implications of our findings for civic education and political theory. 



\section{RELATED RESEARCH}

\section{Political Tolerance}

More than thirty-five years ago, two large national surveys indicated that large majorities of American adults were unwilling to extend procedural rights to nonconformist groups, particularly Communists (Stouffer, 1955). For example, almost two-thirds of the respondents said they would deny an admitted American Communist the right to make a speech in their community. At the same time, they professed strong support for freedom of expression in the abstract.

Since Stouffer's classic study, political scientists and educators have traced the limits of U.S. tolerance, debated its practical and theoretical significance, and argued about the origins of intolerance. Recent research suggests that dogmatism, perceptions of threat, support for abstract democratic values and norms, education, cognitive moral development, and self-esteem are important factors that affect levels of adult political tolerance (McClosky \& Brill, 1983; Sullivan, Piereson, \& Marcus, 1982; Wagner, 1986).

Perhaps the most important debate revolves around the conceptualization of political tolerance. In the late 1970s, Sullivan, Marcus, Piereson and Feldman (1978-79) suggested that tolerance involves "a willingness to apply these [democratic] norms without disfavor to those whose ideas or interests one opposes" [emphasis added] (p. 116). Previous studies had conceptualized tolerance as a willingness to extend rights to political or social groups generally considered marginal or extremist within society, regardless of the respondent's perception of the groups. According to Sullivan et al., tolerance requires dislike or objection; thus the measurement of political tolerance should take into account the individual's attitude toward specific groups.

Using a national sample of 1,509 adults, Sullivan, Piereson and Marcus (1982) initially identified the dissident or nonconformist group that individuals found most repugnant. Although respondents were presented with a list of potential "outcasts," they were also encouraged to name a group other than those listed if appropriate. This was an important departure from previous studies, many of which focused on Communists, and to a lesser degree, atheists and Socialists. Using the respondents' least-liked group, Sullivan et al. then presented them with concrete situations in which they were asked if they would extend basic civil liberties to the group. For example, if a person's leastliked group was atheists, the person was asked to respond to statements such as, "Atheists should be allowed to hold public rallies in our city." In this manner, the researchers believed they had devised a "content-controlled" measure. Although not all researchers support Sullivan et al.'s methodology (see, for example, Sniderman, Tetlock, Glaser, Green \& Hout, 1989), the research has renewed interest and debate about the nature and complexity of political tolerance.

In comparison with the research on adults, studies of political tolerance among children and adolescents are smaller in number and generally less rigorous, both conceptually and methodologically. Still, the research offers some insight into the factors associated with tolerance during this age period. The disparity between support for abstract democratic principles and their application to concrete situations among adolescents parallels that of older generations (Jones, 1980). Similar to adults, the more negatively adolescents perceive a group, the less likely they are to extend rights to the group (Avery, 
1988; Owen \& Dennis, 1987; Zellman \& Sears, 1971). Tolerance seems to be associated with political experiences (Avery, 1988; Jones, 1980), divergent thinking, self-esteem (Zellman \& Sears, 1971), and high levels of cognitive moral reasoning (Avery, 1988; Breslin, 1982; Eyler, 1980; Patterson, 1979).

The dearth of research on adolescent political tolerance is somewhat perplexing, particularly given that much of the change that takes place during adolescence has direct and important implications for developing political orientations, attitudes, and behaviors (Adams, 1985; Sigel \& Hoskin, 1981; Tomey-Purta, 1990). In the next section, we describe research which indicates that this period may be critical to the development of civil liberties attitudes.

\section{A Focus on Adolescence}

The emerging capacity for abstract thought during adolescence provides opportunities to explore the complexity of moral, social, and political issues, and to test competing ideological perspectives and beliefs (Adelson, 1971). Gallatin's (1985) interviews with students in grades six through twelve, for example, suggested an increasing ability among older adolescents to link democratic principles to specific situations, and to appreciate the complex relationship between individual rights and the public good. Such understandings are fundamental to a sophisticated analysis of issues associated with political tolerance.

Zellman (1975) argued convincingly that adolescent political socialization must play a central role in the development of adult attitudes and behaviors on civil liberties issues. By age eleven, if not before, children exhibit attitudes about both the principles of democracy and about the application (or lack thereof) of these principles to unpopular groups. These attitudes appear to be about as consistent as those of many adults in our society (Zellman, 1975; Zellman \& Sears, 1971).

Additional evidence for the potential importance of addressing tolerance during adolescence was provided by Dennis, Lindberg, McCrone, and Stiefbold (1968), who studied children from four nations. Their U.S. sample included children in fifth, eighth, and eleventh grades who were asked to agree or disagree with three statements about tolerance of dissenting minorities: (1) When most of the people want to do something, the rest of the people should not criticize. (2) If a person wanted to make a speech in this city against churches and religion, he should not be allowed to speak. (3) We should not allow people to make speeches against our kind of government. In all three cases, the percentage disagreeing (the more tolerant response) increased substantially from fifth to eleventh grade. The increase on the "not criticize". question was from 9 percent disagree to 33 percent disagree; on the "against churches and religion" question, the increase was from 20 percent to 59 percent; and on the "against our kind of government" the increase was from 33 percent to 64 percent. The same age trends in tolerance for dissent were identified by Famen and German (1972) in their study of five nations, including the United States.

Jones' (1980) secondary analysis of the 1976 National Assessment of Educational Progress (NAEP) data also suggests that an appreciation of rights of expression increases during adolescence. On each of five items related to freedom of expression, seventeen-year-olds demonstrated more tolerant views than their thirteen-year-old counterparts. For example, 40 percent of the younger students surveyed supported citizens' right to criticize the government; 65 percent of the older adolescents expressed similar support. When asked about specific groups, however, the seventeen-year-olds were more reluctant to recognize rights of expression. Although 63 percent felt dissidents ought to be allowed to hold public 
protests, fewer than one-third would allow a member of the Nazi Party to campaign on television (younger students were not asked similar questions).

Research suggests that adolescence is a critical period during which students simultaneously develop support for democratic norms and negative attitudes toward nonconformist groups in society (Jones, 1980; Miller \& Sears, 1986; Owen \& Dennis, 1987). Thus, although most research on political tolerance and support for the Bill of Rights has been conducted on adults, the development of civil liberties attitudes during adolescence has convinced us that the focus of efforts to increase recognition of unpopular groups' civil liberties ought to be on this age group.

\section{The Civics Curriculum and Political Tolerance ${ }^{2}$}

National and international assessments of civics knowledge and attitudes, as well as professional statements and guidelines from the social studies community, reflect a concem for the development of political tolerance among our youth. Recognition and support of constitutional rights, specifically the right to freedom of expression, have been major objectives assessed in national studies (NAEP, 1978, 1980). The twelfth grade version of the most recent national study of civics achievement included eight items directly related to rights of expression (NAEP, 1990). "Support for the right of citizens to express dissent" and "respect for political opposition" were among the objectives deemed important by educational institutions in all nine nations (including the United States) participating in the 1971 IEA study (Tomey, Oppenheim \& Farnen, 1975). In addition, the curriculum guidelines adopted by the National Council of the Social Studies (1979) state that free speech, religious freedom and democratic decision making are essential to human dignity. Although professional educators seem to share the view that political tolerance is important to a democracy, research suggests that the traditional civics curriculum does not engender a strong commitment to tolerance, particularly as it applies to unpopular ideas and groups.

In a review of the empirical studies of schooling and political socialization, Ehman (1980) concluded that conventional civics courses have little if any impact on secondary students' political attitudes. He cited a national survey of high school seniors conducted by Langton and Jennings (1968), in which only very weak correlations were found between the number of civics courses taken in grades ten through twelve and variables such as political interest, efficacy, and civic tolerance. ${ }^{3}$ Scores on a three-item tolerance scale ${ }^{4}$ were not affected by the number of civics courses taken by white students (beta=.06), although civics courses had an impact on tolerance scores among AfricanAmerican students (beta $=.22$ ). The authors interpreted these findings in terms of "information

2 We have limited our discussion to the effects of the traditional civics curriculum. It should be noted that some researchers have addressed other important instructional issues. For example, studies have suggested that an open and democratic classroom climate (Tomey, Oppenheim and Famen, 1975), an instructional emphasis on causes and explanations as opposed to rote memorization in civics classes (Nielsen 1977), and controversial issues discussions (Breslin, 1982; Grossman, 1974) are related to young people's civic tolerance.

3 We are aware of important critiques of the Langton and Jenning (1986) study (see, for example, Hepbum, 1980). However, it remains the only national study which specifically examines the impact of the number of civics courses taken on civic tolerance.

4 The three items were: (1) If a person wanted to make a speech in this community against religion, he should be allowed to speak. (2) If a Communist were really elected to some public office around here, the people should allow him to take office. (3) The American system of government is one that all nations should have. 
redundancy": white students were already exposed to most of the information presented in civics classes, but for African-American students it was new information. It is unclear whether a study of today's students would yield similar results.

When Jennings and Niemi (1981) conducted a follow-up panel study on the same students from the Langton and Jennings (1968) research, they found that educational stratification and achievement played prominent roles in shaping many political attitudes and behaviors in later life. In spite of the fact that civics education per se did not have a direct impact on students, the educational sorting process, which does have a powerful cumulative impact on citizens, had begun. ${ }^{5}$ Jennings and Niemi (1981) did find evidence that many differences among educational strata were prominent during adolescence, even before the college years began.

Jennings and Niemi's (1981) follow-up study also demonstrated that on all three tolerance issues, the effects of educational stratification increased after high school. In fact, they discovered some of the largest differential rates of change between the more and less educated strata on these issues, suggesting a major role for socialization through post-secondary educational experiences. ${ }^{6}$

Zellman, noting the lack of connection between support for democratic principles and their application among secondary students, (1975) argued that:

\section{Civil liberties attitudes are taught mainly in sloganform, without concrete implications being discussed or deduced.... Were the implications of the principles made apparent and the process of deduction presented and practiced, tolerance would likely increase. $(p, 49)$}

There is little evidence that the content of current secondary civics courses has changed much in recent years. High school government and civics texts, which are generally good indicators of what is actually taught in civics classes (Patrick \& Hawke, 1982), continue to emphasize isolated bits of information about governmental institutions and processes. In-depth examinations of key constitutional issues are virtually nonexistent (Carroll et al., 1987; Katz, 1985; Remy, 1981; Patrick, 1991). Patrick and Hoge (1991) suggested that students' tendency to attach greater significance to majority rule than minority rights may be due, in part, to the failure of most textbooks to address the latter issue. In an effort to avoid potential controversy, most textbook publishers give such questions only superficial coverage. It is doubtful, therefore, that current civics curricula can be expected to help young people develop a sophisticated understanding of democratic principles. In a recent summary of the impact of civic education, Corbett (1991) concluded:

While democratic political principles are taught, they are taught as slogans rather than as applications.... Children are not taught to apply these principles to actual situations.... As a result...the typical American adult is not very supportive of specific applications of democratic principles. (p. 213)

5 There is evidence that in Britain, civics curricula have an impact on political knowledge, sophistication, cynicism, and efficacy, but not on political tolerance (Denver \& Hands, 1990).

6 Despite these findings with respect to students, others have shown that education and tolerance are correlated among adults (e.g., Bobo \& Licari, 1989; McClosky \& Brill, 1983) and among young adults (Montero, 1975). These findings reinforce the suggestion that much civil liberties socialization occurs after high school, either through curriculum effects in college or, more likely, through a broader social leaming process that occurs both in and outside of the college classroom. Altemayer (1988) provides evidence that college vitiates authoritarianism by providing a diversity of experience and exposure to ideas that does not occur as frequently or profoundly among citizens who do not attend college. He finds little evidence to link authoritarianism among college students directly to the effects of curriculum. 
These remarks are vividly reminiscent of Zellman's observations over fifteen years ago.

There is some evidence that innovative curricula can increase support for civil liberties. Goldenson (1978) examined the potential of curriculum materials specifically developed for civil liberties education. He found statistically significant differences in the changes in attitudes and concern for civil liberties among students who studied this curriculum compared to a control group that studied economics. The former were exposed to a three-week unit on civil liberties which was designed to "put more than the usual stress on the implications of abstract constitutional civil libertarian principles in concrete situations" (p. 50).

From a different analytic perspective, which entailed the use of cross-national survey research methods, Sullivan, Shamir, Walsh, and Roberts (1985) discovered that an understanding of the concrete legal basis of democratic principles had a greater impact on political tolerance than did support for the abstract norms themselves. This research reinforces Zellman's suggestion that a curriculum designed to increase support for civil liberties in concrete situations should focus on how the legal and constitutional framework of our society directly embodies the norms of freedom of speech and minority rights, and how these norms and laws can be applied in specific situations that test our society's political tolerance.

In conjunction with a small number of secondary civics teachers, we have developed a curriculum that incorporates all of these suggestions. In the following sections we describe the curriculum, its impact on students' levels of political tolerance, and other variables which may contribute to adolescent tolerance. 


\section{.}




\section{METHOD}

\section{Tolerance for Diversity of Belief: A Curriculum}

Tolerance for Diversity of Belief is a four-week curriculum unit designed to engage junior high students in the active exploration of issues associated with freedom of belief and expression. ${ }^{7}$ Unlike many instructional materials, the lessons have been shaped by theory and research on political tolerance. Particularly, we have attempted to respond to the weight of research suggesting that when people understand how the abstract principles of freedom of speech and minority rights are embedded in a system of legal protections and rights, they are more likely to acknowledge the civil liberties of unpopular groups. Throughout the curriculum, students systematically examine the ways in which the legal and constitutional framework of our society directly embodies the norms of freedom of speech and minority rights. Students analyze the legal protections that have been accorded unpopular groups at the national level and the parallel principles that are embodied in the Universal Declaration of Human Rights at the international level. Case studies, role playing, simulations, and mock interviews are used throughout the curriculum to examine the historical, psychological, and sociological dimensions of tolerance and intolerance. Specifically, information from psychological studies helps students understand why some individuals are particularly intolerant of beliefs that differ from their own. Descriptions of the Holocaust, the Cultural Revolution, and the internment of Japanese-Americans during World War II direct students' attention toward the short- and long-term consequences of intolerance for the victim, the perpetrator, and society.

Within the curriculum, students consider both the rights and responsibilities associated with freedom of expression. For example, if one strongly disagrees with the beliefs of the Ku Klux Klan, does one have both a right and a responsibility to express disagreement? What rights and responsibilities do members of unpopular groups have? A series of vignettes encourages students to decide for themselves what limits, if any, should be placed on freedom of expression in a democratic society. Questions guide students toward differentiating between acknowledging an unpopular group's civil liberties and approving of the group's message, between beliefs that are abhorrent to the majority and behaviors that are violent and harmful. (See the appendix for a more detailed description of the curriculum.)

The primary goal of the curriculum is to help students understand how the abstract principles of freedom of speech and minority rights are embedded in our legal framework. If Zellman (1975) and Corbett (1991) are correct, the young people who participate in the curriculum will be more likely to acknowledge the civil liberties of unpopular groups. As an educational tool, however, the curriculum is also designed to challenge intolerant and tolerant students' thinking about the role of freedom of expression in a democratic society. Regardless of whether students choose to acknowledge the

7 We do not claim that ours is the only curriculum that addresses these issues. Many of the law-related education materials provide in-depth analysis of civil liberties issues. However, we are unaware of any studies that measure the impact of these curriculum materials on political tolerance. 
rights of dissidents or outcasts as a result of the curriculum, it is hoped that they will develop a more complex understanding of civil liberties issues. ${ }^{8}$

\section{The Students, the Schools, and the Design}

In the spring of 1991, we conducted a comprehensive test of the effects of our tolerance curriculum. A description of the students, teachers, and schools involved in the study is shown in Table 1. We analyzed the effects of the curriculum on ninth grade students, all of whom were assigned to treatment groups based on intact classrooms. The groups were as follows:

- Curriculum Group: 274 students completed the pretest, the four-week curriculum, and immediately thereafter the posttest.

- Delayed Posttest Group: 70 of these 274 students also completed a delayed posttest one month after they completed the curriculum and the first posttest.

- No Curriculum Group: 168 students completed the pretest and, four weeks later, the posttest; they did not study the curriculum - instead they studied their regular civics curriculum.

- Delayed Curriculum Group: 59 of these 168 students also served as their own control group: they took the pretest, studied their normal civics curriculum, took the posttest four weeks later, then studied the tolerance curriculum and took a second posttest immediately upon its completion.

This arrangement allowed us to examine the impact of the tolerance curriculum in several different ways. First, we examined differences in levels of tolerance among all groups at the beginning of the study, as well as any changes that occurred over time. Second, we wished to examine changes and differences in the levels of threat, wary that apparent increases in students' levels of tolerance may have been due to declining fear or dislike of their least-liked group. Third, we were able to examine the impact of the curriculum by regressing posttest tolerance scores for the Curriculum Group on curriculum measures, such as a knowledge test, using pretest tolerance scores and other known independent variables as covariates. Finally, responses to two open-ended questions were examined; these items asked students to explain why they had adopted tolerant or intolerant stances. With this multifaceted approach, we hoped to attenuate the problems caused by our lack of control over assignment of students to classrooms.

8 Critics may contend that the curriculum is indoctrination as opposed to education. Indeed, this issue has prompted not a few lively discussions among us. No curriculum is devoid of values, and our curriculum is no exception. We do, in fact, believe that tolerance for diverse beliefs is critical to a democracy, and hence is an important area of inquiry within citizenship education. On this point, we appear to be joined by governmental agencies and professional education organizations (NAEP, 1978, 1980); National Council for the Social Studies, 1989). It is also our belief, and the one tested here, that if students carefully examine the consequences of intolerance for the victim, the perpetrator, and society, they will be more likely to choose more tolerant stance.

Our curriculum however, does not provide "right" answers; rather, it poses questions that should be challenging to both tolerant and intolerant viewpoints. Lessons do not condone violence; nor do they encourage students to approve of the beliefs of specific political groups (on the contrary, students are reminded of their right to express disagreement with groups whose ideas they find noxious). Further, at no point during the curriculum are students "graded" on their views with regard to civil liberties issues. 
Table 1. School, Classroom, and Teacher Characteristics

Characteristic School A School B

School C

Profile of School

Location

Urban city of 370,000

Grade levels

Grades 9-12

Total number of students

1,848

Rural city of

Rural city of

11,000

11,000

Grades 7-9

Grades 7-9

681

677

\section{Classroom composition}

People of color (in comparable population)

statewide

schoolwide

in curriculum group

in no curriculum group

$9 \%$

$44 \%$

$46 \%$

$22 \%$

Gender
statewide
schoolwide
in curriculum group
in no curriculum group

Students in Curriculum Group

Students in No Curriculum Group

Students in Delayed Posttest Group

Profile of Teachers

$\begin{array}{cc}\text { M } & \text { F } \\ 51 \% & 49 \% \\ 57 \% & 43 \% \\ 44 \% & 56 \% \\ 29 \% & 71 \%\end{array}$

38

45

0

White male, 29

years experience
$9 \%$

$1 \%$

$5 \%$

$2 \%$

$\begin{array}{cc}\text { M } & \text { F } \\ 51 \% & 49 \% \\ 48 \% & 52 \% \\ 45 \% & 55 \% \\ 29 \% & 71 \%\end{array}$

75

91

32

70

0

$9 \%$

$1 \%$

$5 \%$

$7 \%$

161

$\begin{array}{cc}\text { M } & \text { F } \\ 51 \% & 49 \% \\ 51 \% & 49 \% \\ 47 \% & 53 \% \\ 42 \% & 58 \%\end{array}$

White male, 15 White female, 17 years experience years experience, and white male, 4 years experience

\section{Measures}

During the pretest and various posttests, we collected data on a number of concepts. The dependent variable in this analysis is political tolerance; the independent variables include support for democratic norms, perceived threat, authoritarianism, knowledge of the curriculum, attitude toward the curriculum, and three standard demographic variables (race, gender, and grades in school).

Political Tolerance. We have adopted Sullivan and his colleagues' (1982) conceptualization of political tolerance, i.e., individuals cannot be "tolerant" of those of whom they approve. If they approve of a group, they may "support" it but not "tolerate" it. If they do not care about a group, they are "indifferent" but not "tolerant." By this definition, political tolerance requires that persons recognize the civil liberties of groups with whom they disagree. Thus, in order to assess tolerance, we asked 
students to evaluate (like-dislike) a number of potentially unpopular groups from both sides of the political spectrum using a five-point Likert scale. Students performed this evaluation twice, once on the pretest and again on the posttest. The students were then asked to specify which group they liked the least. ${ }^{9}$ About 72 percent of students chose the same least-liked group at both points in time. ${ }^{10}$

Once students had specified a group, each student was asked six questions concerning the rights that should be extended to his or her least-liked group. The following questions compose the tolerance scale (we will use the Ku Klux Klan as an example):

1. Members of the [Ku Klux Klan] should not be able to run for president or other elected offices.

2. Members of the [Ku Klux Klan] should be allowed to teach in public schools.

3. The [Ku Klux Klan] should be against the law.

4. Members of the [Ku Klux Klan] should be allowed to make a public speech.

5. The government should be able to tap the phones of members of the [ $\mathrm{Ku} \mathrm{Klux} \mathrm{Klan].}$

6. The [Ku Klux Klan] should be able to hold public demonstrations or rallies.

Each tolerance question had five possible responses, ranging from strongly agree to strongly disagree. The most tolerant response was assigned a 5 and the least tolerant response a 1 . The tolerance scale therefore ranges in value from 6 to 30 . Coefficient alpha on the pretest was .74; it was .79 on the posttest.

Support for Democratic Norms. Previous research on democratic norms and values found that United States citizens were overwhelmingly supportive of freedom of speech and minority rights in the abstract, but not when applied to unpopular groups (McClosky, 1964; McClosky \& Brill, 1983; Prothro \& Grigg, 1960; Sullivan et al., 1982). The usual conclusion has been that although ordinary citizens endorse these norms, they rarely translate them into practice. It is true, however, that there is a relationship between a strong endorsement of democratic values, and political tolerance toward one's least-liked group (Sullivan et al., 1982).

Given these results-as well as the underlying premise of the curriculum we developed-support for abstract democratic norms was measured by responses to six standard items, including "I believe in free speech for everybody, no matter what their views might be" and "Society shouldn't have to put up with those who have political ideas that are extremely different than the majority." The resulting scale had a reliability of .63 .

9 For a more thorough discussion of this conceptualization and measurement of political tolerance, see Sullivan et al. (1982).

10 Seventy-three percent of the students in the control group chose the same least-liked group at both points in time; the fact that similar results were obtained among students in the experimental group indicates that the curriculum does not affect students' attitudes toward their least-liked group.

Among experimental and control groups, on both pretests and posttests, approximately two-thirds of the students chose the Ku Klux Klan as their least-liked political group. American Nazis and pro-choice groups were selected by approximately 15 percent of the students. Each of the other groups (American Communists, peace activists, pro-life groups, war supporters, groups who support women's rights, and groups who want rights for people of color) were chosen by less than 10 percent of the students. 
Perceived Threat. Previous studies of political tolerance have suggested that perceived threat of a least-liked group is an important determinant of intolerance among adults (McClosky \& Brill, 1983; Stouffer 1955; Sullivan et al., 1982; Sullivan et al., 1985) and young people (Avery, 1988; Patterson, 1979; Zellman \& Sears, 1971). We asked students to describe their least-liked group using a series of polar adjectives: safe-dangerous, good-bad, nonthreatening-threatening, can be trustedcannot be trusted, and nonviolent-violent. The polar terms were presented in a five-point scale with the terms anchoring the ends, giving students the opportunity to provide a self-calibrated response. For each adjective pair, we assigned a score of 5 to the most threatening term and 1 to the least threatening term, with the scale thus ranging from a low of 5 to a high of 25 . Coefficient alpha was .86 on the pretest and .87 on the posttest.

Authoritarianism. Past research on adults has suggested that psychological insecurity and authoritarianism have a strong impact on intolerance (McClosky \& Brill, 1983; Sniderman, 1975; Sullivan et al., 1982). We developed a scale of authoritarianism that includes measures of submission to existing authority, authoritarian aggression, conventionalism, and dogmatism (Altemeyer, 1988; Rokeach, 1960). The full scale had an overall reliability of .59. Representative items include: "Anyone who is homosexual is sick" and "To keep society orderly we must all obey the police."

Self-Esteem. Levels of self-esteem have been significantly related to levels of tolerance in adults (Sniderman, 1975; Sullivan et al., 1982), but the literature linking tolerance and self-esteem in adolescents has produced mixed results (Zellman \& Sears, 1971). In this research, we used Rosenberg's (1965) measure of self-esteem. The measure includes eleven statements such as "I feel that I have a number of good qualities," and "I feel I do not have much to be proud of." Students responded by indicating whether they strongly agreed, agreed, disagreed, or disagreed strongly with each statement. Coefficient alpha for the scale resulting from this measure was .86 .

Knowledge of Curriculum Content. We measured students' knowledge of the curriculum on the posttest by using nine true/false questions representative of the material covered in the curriculum ("The United States is the only country with a constitution that protects the free expression of ideas." "It is against the law to belong to a racist group like the Ku Klux Klan."). The alpha coefficient for this scale, which ranged from 0 to $9(0=$ all wrong answers and $9=$ all correct answers $)$, was .83 .

Attitude Toward the Curriculum. On the posttests, we used polar terms to have the students indicate their reaction to the curriculum. The terms used were dull-interesting, fun-boring, and likedislike. The alpha coefficient for this scale was 89 .

Demographic Variables. Research in the 1950s suggested that demographic variables were associated with political tolerance, finding that more highly educated people (with higher incomes generally) were more tolerant of outgroups such as Communists and atheists and that men were more tolerant than women (Stouffer, 1955). However, after controlling for target group, gender differences virtually disappeared. Sullivan et al. (1982) suggested this occurred because women were more religious than men and were more intolerant of atheists. Education continues to make a slight difference in levels of tolerance even in content-controlled studies (Sullivan et al., 1982), but the differences are reduced. 
Among adolescents, studies of the influence of demographic variables such as race and gender on political tolerance have produced mixed results. When statistically significant differences have been noted, they are quite modest (Avery, 1988).

In the present study, information regarding three demographic variables was collected: race, gender, and grades. Students were asked to report the grades they "usually" receive in school: A to A-, B+ to $\mathrm{B}-, \mathrm{C}+$ to $\mathrm{C}-, \mathrm{D}$ or below. 


\section{RESULTS}

\section{The Curriculum and Increases in Political Tolerance}

A primary question of interest to this study is whether students displayed increased levels of political tolerance after participating in the curriculum. Contrary to the general finding that civics curricula do not affect adolescents' levels of tolerance, the curriculum does seem to increase students' levels of tolerance toward disliked political groups. ${ }^{11}$

Because we were unable to randomly assign students to classrooms, we conducted the series of analyses mentioned earlier, designed to assess the impact of the tolerance curriculum. First, we conducted one-way analyses of variance to determine whether there were statistically significant differences between the Curriculum Group and the No Curriculum Group on political tolerance and perceived threat scores. The results, as shown in Table 2 , indicated no significant pretest differences between the groups (for tolerance, $\mathrm{p}=.877$; for threat $\mathrm{p}=.993$ ), despite our lack of random assignment. 12

As a result of this lack of pretest differences, we will use analysis of variance to compare the Curriculum and the No Curriculum Groups. Table 3 shows the results of this analysis for both political tolerance and perceived threat. The most important finding about political tolerance is the significant interaction between condition (curriculum v. no curriculum) and time (pretest v. posttest). Time matters differently for the two groups of students-political tolerance scores increase more among students who studied the curriculum than among those who did not. The effect size for time is .25 and for the interaction between time and curriculum condition is .15. Both of these effects are modest, but highly statistically significant. The mean for the Curriculum Group increased from 15.35 to 17.55 , while the mean for the no Curriculum Group increased from 15.28 to 15.85 . This effect is above and beyond the main effects of both condition and time. Although both groups showed some increase in tolerance, this increase was small among the No Curriculum Group, and significantly greater among Curriculum Group. This suggests that the significantly increased tolerance of the Curriculum Group is a reflection of the curriculum intervention, rather than differences between the groups, or natural changes that may occur among these adolescents over time.

11 The curriculum was initially piloted in the spring of 1990 with 271 eighth and ninth-grade students from three public junior high schools in the state of Minnesota (see Avery, Bird, Healy, Sullivan \& Thalhammer 1991). The 1990 study did not include a control group. Results of the 1990 study, however, are quite similar to those found in the 1991 study, thereby increasing our confidence in the results reported here. In 1990, students who participated in the curriculum demonstrated a statistically significant increase in political tolerance $(t=-8.81 \mathrm{p}<.001)$. On the pretest regression analysis, political interest perceived socioeconomic stanus and perceived threat were significant predictors of political tolerance. On the posttest regression analysis, gender, grades, perceived threat, curriculum knowledge, and pretest tolerance were significant predictors of tolerance. Measures of authoritarianism and support for democratic norms were not included in the earlier study.

12 Chi square analyses were conducted to detect any difference between groups on independent variables. This analysis revealed that students in the No Curriculum Group were significantly more likely to be younger, to be people of color, to be female, and to report higher grades and self-esteem than were students in the Curriculum Group. 
The second test of the curriculum involves using the Delayed Curriculum Group as its own control. Recall that these students completed the pretest measures, stuctied a regular civics unit for four weeks, and then took the posttest. For the next four weeks, they studied the tolerance curriculum and took the posttest afterwards. They were taught throughout the entire eight weeks by the same teacher. Repeated measures analysis of variance for the Delayed Curriculum Group indicates no statistically significant change in tolerance during the control phase $(\mathrm{p}=.205)$, followed by a significant increase during the curriculum phase $(p<.000)$. The mean scores of these students changed from 16.29 to 17.00 to 19.70 across the three testing periods (see Table 4), and the effect size was a very robust .63. The results are strikingly similar to the comparison between the Curriculum and No Curriculum Groups: beth groups demonstrated statistically and substantively significant changes in levels of tolerance when participating in the tolerance curriculum, but not when studying the traditional civics curriculum. Before studying the curriculum, the typical student scored almost two points below the midpoint of the political tolerance scale; after studying the curriculum, such a student scored almost two points above the midpoint. In other words, most students went from mild intolerance to mild tolerance, a substantively important change. This adds credence to the claim that the tolerance curriculum does have an impact on students.

Table 2. Political Tolerance and Perceived Threat (Means and Standard Deviations)

\begin{tabular}{lccccc} 
Score & \multicolumn{2}{c}{$\begin{array}{c}\text { Curriculum } \\
\text { Group }\end{array}$} & \multicolumn{2}{c}{$\begin{array}{c}\text { No Curriculum } \\
\text { Group }\end{array}$} \\
\hline Pretest Political Tolerance & 15.35 & $(5.37)$ & 15.28 & $(5.17)$ \\
Posttest Political Tolerance & 17.55 & $(5.47)$ & 15.85 & $(5.69)$ \\
Pretest Perceived Threat & 22.14 & $(3.46)$ & 22.28 & $(3.23)$ \\
Posttest Perceived Threat & 22.19 & $(3.75)$ & 22.27 & $(3.61)$ \\
\hline
\end{tabular}

(Standard deviations in parentheses)

Table 3. Analysis of Variance Between and Within Subjects (Political Tolerance and Perceived Threat)

\begin{tabular}{lccccc} 
& \multicolumn{2}{c}{ Political Tolerance } & \multicolumn{2}{c}{ Perceived Threat } \\
Effect & $p$ & Effect Size* & $p$ & Effect Size* \\
Condition & .058 & .090 & .703 & .018 \\
Time & .000 & .250 & .897 & .006 \\
Condition x Time & .002 & .150 & .871 & .008 \\
\hline
\end{tabular}

* Effect size $=\sqrt{(t 2 / 2)+(n-2)}$ 
Table 4. Repeated Measured Analyses of Variance for Political Tolerance and Perceived Threat: Delayed Curriculum Group

\begin{tabular}{llcc} 
Variable & Comparisons* & $p$ & Effect Size** \\
\hline Political Tolerance & Mean (1) and Mean (2) & .205 & .177 \\
& Mean (1) and Mean (2) with Mean (3) & .000 & .630 \\
Perceived Threat & Mean (1) and Mean (2) & .682 & .058 \\
& Mean (1) and Mean (2) with Mean (3) & .755 & .044 \\
\hline $\begin{array}{l}\text { * Mean politial tolerance scores for times 1, 2, and 3 were 16.29, 17.00, and 19.70; mean perceived threat scores were 21.64, } \\
\text { 21.42, and 21.65. } \\
* * \text { Effect size }=\sqrt{F /(F+d f \text { in error term) }}\end{array}$
\end{tabular}

The third test involves examining whether the curriculum has a brief impact due to increasing temporarily the salience of a set of "right answers," or whether it has a more lasting impact due to learning. Delayed posttest scores for Delayed Posttest Group were collected and compared to pretest scores to examine any persistent effects of the curriculum. Four weeks following the conclusion of the tolerance unit, the tolerance scores of these 70 students remained significantly higher than their pretest scores $(p=.01$ ); the mean scores of these students changed from 16.61 to 19.66 to 18.50 . Thus, it seems likely that the change is not entirely ephemeral, but may be due, in part, to learning that lasts beyond the curriculum experience itself.

All of these findings lend strong support to the conclusion that the curriculum does increase students' levels of tolerance toward disliked groups.

\section{The Curriculum and Threat Perceptions}

In the pretest data, and in many other data sets, threat perceptions are among the strongest factors influencing tolerance. To examine whether the curriculum increased tolerance among students in the Curriculum Group by reducing the extent to which they feel threatened by their least-liked group, we performed a second set of analyses of variance, this time on pretest and posttest levels of perceived threat. Table 3 shows the results for a analysis of variance for threat scores of the Curriculum Group. None of the differences are statistically significant, indicating that threat scores were stable for both groups, regardless of whether they studied the tolerance curriculum. Table 4 shows the same results for the Delayed Curriculum Group, the group that served as its own control: levels of threat were constant over the two four-week periods for this group.

It is an important finding that while levels of tolerance increased, neither students' dislike of their least-liked group nor their threat perceptions changed significantly. Levels of dislike were similar before and after studying the curriculum, with only one exception: students disliked American Nazis more after studying about them. ${ }^{13}$ In terms of statistical significance, there were no other groups for which students' evaluations differed after studying the curriculum.

13 The curriculum has two case studies that involve the Nazis, their rights, and the victims of their intolerance. 
The findings on levels of threat are important because they suggest that students' increase in political tolerance is not primarily the result of declining dislike or fear of these groups. Recalling the nature of many disliked political groups in our society-e.g., the Ku Klux Klan, Nazis-we would view such an outcome with dismay. Given our understanding of tolerance, we hoped that the curriculum would instead teach students to be tolerant given that they dislike a particular group. Increased tolerance may be due to other factors such as an increased ability to show forbearance in the face of threat.

\section{A Multivariate Analysis of Political Tolerance}

Having demonstrated that students' levels of tolerance increased is only part of the picture. We explored the effects of the curriculum on different types of individuals, examining the effects of demographic variables (race, gender, and grades in school) on changes in tolerance. We also examined the effects of variables such as knowledge and enjoyment of the curriculum, and level of perceived threat.

Two sets of regression analyses were run, the first to examine the causes of students' levels of political tolerance prior to curricular instruction, and the second to determine some of the effects of the curriculum (Table 5). Prior to students' participation in the curriculum, perceived threat was a significant predictor of political tolerance.

Table 5. Pre- and Posttest Regression Analyses**

Pretest Posttest

Unstandardized Standardized Unstandardized Standardized

\begin{tabular}{lcccc} 
Variable & Coeffic. & Coeffic. & Coeffic. & Coeffic. \\
\hline Gender & .03 & .00 & -.62 & -.06 \\
Grades & -.59 & -.07 & -.26 & -.03 \\
Perceived threat & $-.59^{*}$ & $-.39^{*}$ & $-.36^{*}$ & $-.26^{*}$ \\
Authoritarianism & -.15 & -.11 & $-.29^{*}$ & $-.23^{*}$ \\
Democratic norms & .19 & .12 & $.22^{*}$ & $.14^{*}$ \\
Self-esteem & .02 & .02 & $.15^{*}$ & $.12^{*}$ \\
Curriculum knowledge & & & $.37^{*}$ & $.11^{*}$ \\
Enjoy curriculum & & & -.09 & -.05 \\
Pretest tolerance & & & $.47^{*}$ & $.46^{*}$ \\
\multicolumn{1}{c}{ Constant } & & & 14.67 & \\
Adjusted R-Square & 27.53 & .43 & \\
\hline
\end{tabular}

* Significance $<.05$

** Tests indicate no significant departure from linearity or homoscedasticity in either equation. 
Support for democratic norms among these adolescents was a significant predictor of actual levels of political tolerance on the posttest, but falls just below significance on the pretest. As support for democratic norms is measured at the pretest and not at the posttest phase, it is possible that students may have demonstrated an increase in their support for democratic norms which corresponded with their increase in tolerance. This seems likely, given the curriculum's emphasis on the principles as well as the application of civil liberties and would not contradict the repeated findings that support of democratic principles is seldom translated into their application to disliked groups. A closer examination of the regression findings indicated little change in the regression coefficient or t-values from pretest to posttest.

Levels of perceived threat were strongly and negatively related to political tolerance prior to students' introduction to the curriculum. If groups were perceived by students as very threatening, they tended to be denied most democratic rights. While the relationship persists in the posttest results, it is much weaker. The curriculum seems to attenuate the link between threat and tolerance; although the perception of threat remains salient to students, there are a range of considerations that intervene between what has been demonstrated to be a striking cause and effect relation between threat and intolerance.

One of the strongest predictors of posttest tolerance levels (other than pretest levels) is students' knowledge of the curriculum material. Simply put, knowledge of lesson content contributed substantially to higher levels of tolerance. Grades and enjoyment of the curriculum, however, have little effect.

Authoritarianism is a strong predictor of posttest tolerance, but not (all else equal) pretest tolerance. This was an intriguing finding, and led us to suspect that certain students may have been reacting against the curriculum. To explore this further, we compared students who exhibited the highest increases in tolerance with those who showed the greatest decrease in political tolerance on many characteristics. We found several significant quantitative differences between them, but most importantly, those who decreased in tolerance scored much higher on our measure of authoritarianism. Interestingly, they were significantly less threatened on the pretest but significantly more threatened on the posttest than students who increased the most in terms of political tolerance. At this point, our conjecture is that some adolescents are highly authoritarian and when they experience a curriculum designed to promote tolerance, they react against it, perhaps becoming more defensive, fearful, and thus less tolerant.

Finally, self-esteem is positively related to levels of posttest tolerance, but not to pretest tolerance. These findings appear to demonstrate support for the suggestion that negative self-attitudes interfere with social learning (McClosky \& Brill, 1983; McClosky \& Zaller, 1984; Sniderman, 1975). Not surprisingly, self-esteem is positively correlated with students' grades in school $(r=.18, p<.01)$. And, in correspondence with most research on adolescent self-esteem, girls in our sample have significantly more negative self attitudes than boys $(r=-.27, p<.01)$. Yet, the regression findings demonstrate the significant effect of self-esteem, even controlling for students' grades and gender. We suggest that the effects of low self-esteem are similar to those of high authoritarianism among adolescents. Negative self-esteem appears to impede upon students' ability, and possibly their motivation, to learn more tolerant behavior through the lessons of the curriculum. Possibly such individuals are more defensive and fearful of information which challenges their ideas about social norms. That pretest tolerance levels remain the strongest predictor of posttest tolerance is a matter which merits attention. The attitudes 
students bring to their civics classes (and to the curriculum) are informed by many broad factors of socialization which we have neither measured nor affected in the course of this project. Many of these factors are related to attitudes that have been fostered in the home, particularly by parents and mass media as transmitters of general cultural views on topics of tolerance and intolerance. We do not expect that our curriculum overcomes all of the entrenched and intolerant ideas that young people learn from adults and society more generally. Although our findings leave much of the origins of tolerant and intolerant attitudes unexplored, the results of our initial study suggest changes important enough to warrant cautious optimism.

\section{Students' Explanations for Tolerant/Intolerant Responses}

In an effort to better understand students' responses, we included two open-ended questions on the pretest and posttest. In this section, we report our analysis of a small sample of students' responses to the openended items. Forty-four students' pre- and posttests were selected for analysis on the basis of pretest political tolerance scores: twenty-two of the students had the lowest pretest tolerance scores of the sample who studied the curriculum, and twenty-two had the highest pretest tolerance scores. Responses provide further insight into the nature of tolerance and intolerance; in addition, they lend support to our interpretation of the quantitative analysis.

The open-ended items required students to explain their views on whether their least-liked group should be allowed to hold a public rally, and also to comment on what they thought would happen if the group did hold such a rally. Table 6 provides an explanation of the coding categories.

We examined responses from four groups of students: (1) low pretest and posttest tolerance scores, (2) low pretest and high/moderate posttest tolerance scores, (3) high pretest and posttest tolerance scores, and (4) high pretest and low/moderate posttest tolerance scores. Recall that we originally selected equal numbers of extremely tolerant and intolerant students based on pretest scores (twenty-two students in each group). The posttest scores of these students, however, were not similarly divided. Because most students' tolerance scores increased after the curriculum, there were relatively few students whose tolerance scores declined from high to low. 


\section{Table 6. Reasons for Allowing/Disallowing Least-liked Group to Rally}

They are wrong - Disliked group has no right, or should not be allowed, to hold rally because their reasoning or views are inappropriate.

Recruitment-Concern that disliked group will influence people and increase its popular support.

Danger -Disliked group would engage in dangerous activities, or violence would erupt between disliked group and protesters.

Rights-Any mention of a constitutional or a fundamental right or privilege that should be granted to all people.

Exchange Views/Protest -Potential for exchange of views or peaceful protest among competing groups or ideas.
- They have no right to put down another race because they think they are better.

- No group should be able to hold rallies to tell people: "Hate these people because they are not our color!"

- They'll speak and more people will want to join in.

- If they convinced people to join them, many more people will be hurt by their actions.

- It would get out of hand. They would kill people who don't agree with them. It would not be a nice sight.

- I think it would be a mess. A riot would probably start.

- They have every right to assembly, just as much as you or me.

- Everyone holds first amendment rights no matter what they believe.

- There would be opposition, but if it was peaceful it would go alright.

- If there would be one, there would be some peace rallies too. 
Figure 1 shows the changes in explanations from pretest to posttest. Among the twenty-two students who had the lowest pretest tolerance scores, levels of tolerance remained low for eleven students and increased to the middle or top third of the possible range of scores for the other eleven students.

Among the eleven students whose levels of tolerance remained low, the majority of responses on the preand posttests indicated a high level of concern for the potential danger posed by the disliked group. Nine students on the pretest and eight on the posttest were willing to deny the right to hold a rally because of the fear of violence. In comparison, only three students used the language of rights on either pre- or posttest, and only one referred to the possibility of a peaceful exchange of views. Students with low pretest tolerance scores also tended to deny the right to rally on the basis that their disliked group holds wrong or bad ideas. However, the number of these responses declined to zero on the posttest.

Figure 1. Changes in Adolescents' Rationales for Tolerant/Intolerant Responses ${ }^{14}$

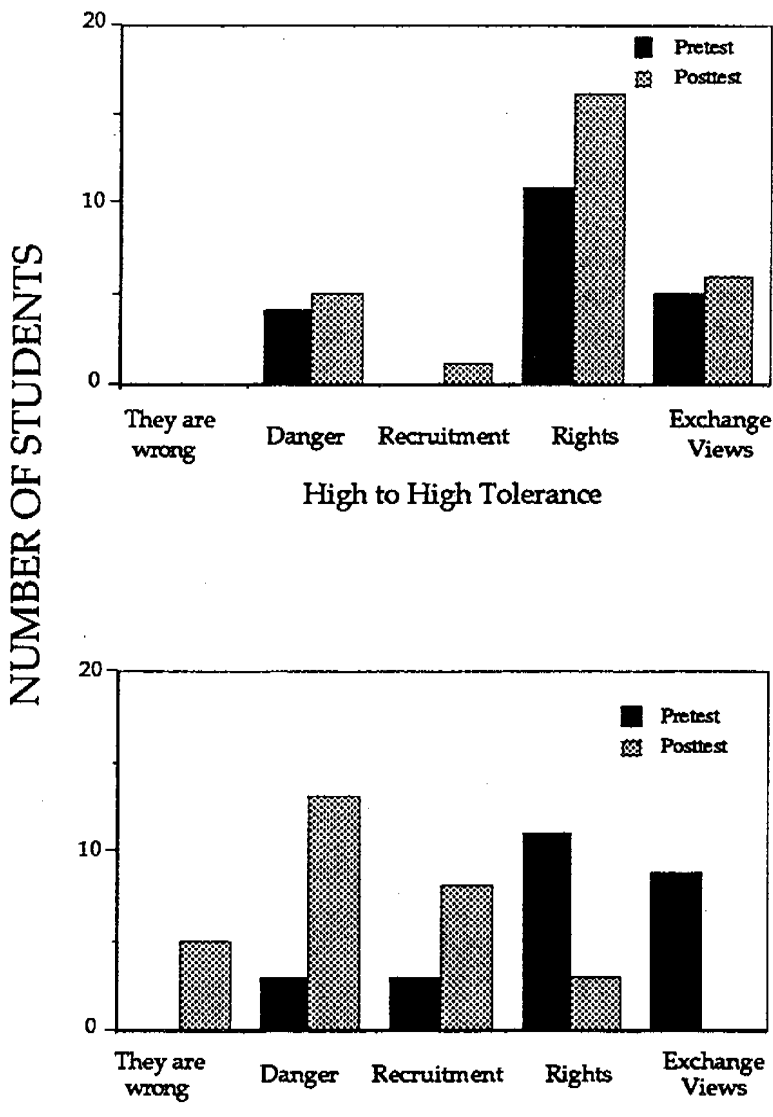

High to Moderate/Low Tolerance
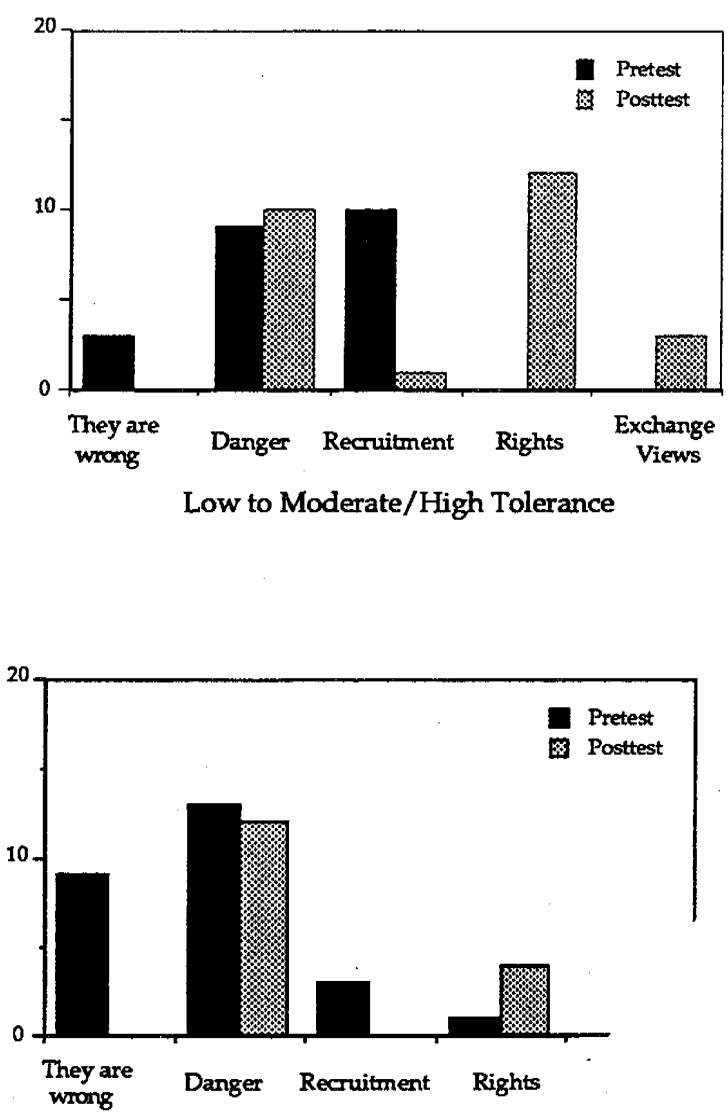

Low to Low Tolerance

14 For comparison purposes, all scores have been standardized to $n$ of sixteen. Actual raw numbers are reported in the text. For example, the actual number of students who had low tolerance scores on the pretest and posttest was eleven. The actual number of students' responses coded in the "They are wrong" category on the pretest was six. For the visual representation shown in Figure 1, the number of students was calculated as follows: actual number of responses times sixteen, divided by actual number of students in low-low group. 
On the other hand, among the eleven whose posttest scores increased significantly, none used the language of rights on the pretest, while eight did so on the posttest. Perceptions of danger remained fairly high for these students from pretest to posttest, despite their increase in tolerance. This reinforces our earlier finding that learning about tolerance tends to decouple the issue of perceived threat from tolerance and makes perceived threat less salient when deciding whether to extend certain rights to groups. However, concerns about recruitment declined dramatically for students in this group. Among the students who were initially lowest in tolerance, then, a new focus on "rights" (presumably gained from our curriculum) distinguishes those whose tolerance increases significantly from those whose tolerance remains relatively low.

We also analyzed the responses of the twenty-two students whose pretest tolerance scores were highest. Among the sixteen whose scores remained high, eleven used the language of rights on the pretest while all sixteen did so on the posttest. Also interesting is the number of high tolerance students who referred to the potential for exchange of views among groups. Five students mentioned this on the pretest and six did so on the posttest. The high tolerance students who remained high demonstrated somewhat less concern over the threat of danger and violence in their explanations than did those whose scores declined: only four highly tolerant students mentioned violence on the pretest and five cited violence on the posttest.

Among the six students whose tolerance scores decreased from high to low, there was an increase in references to danger or violence, with one student mentioning violence on the pretest and five students citing violence on the posttest. There was also an increase in the "they are wrong" category, a corresponding decline in the number of students mentioning rights at the pretest stage (four) and at the posttest stage (one), and a decline in the number of students recognizing the possibility of exchanging views at a rally (three to none). This suggests that these students may have reacted against the curriculum. They were not worried about danger or violence, or potential recruitment by the group before studying the curriculum and focused instead—as did the high-high group —on "rights." Studying the curriculum appears to have activated their fears about the group's danger and strength, thus diminishing their focus on the group's right to demonstrate.

Responses to the open-ended items on the surveys therefore give us greater insight into the nature of tolerance and intolerance, and why changes may occur in response to the curriculum. In general, it appears that increases in tolerance levels are due to a greater focus on rights, whereas decreases in tolerance levels may be attributed to heightened concerns for safety. 



\section{DISCUSSION AND IMPLICATIONS}

Research on civics curricula as they are currently constituted suggests that they have little impact on the political attitudes of American youth (Ehman, 1980). However, one ought not conclude from this research that a reconstituted civics curriculum would be ineffective. Our work suggests that such a reconstitution might engender a greater tolerance for diversity of beliefs. A curriculum that helps students comprehend the consequences of intolerance can increase students' willingness to extend rights to disliked groups. In short, political tolerance can be taught.

Importantly, our testing of the curriculum seems to indicate that it is effective under vastly different classroom conditions. Students' levels of tolerance increased at all three schools at about the same rate. It might have been expected, given the findings of Langton and Jennings (1968), that tolerance would increase more at the urban school whose student population includes a larger proportion of students of color. However, the information redundancy Langton and Jennings discovered among whites did not occur in our study. The contents of the curriculum appear to have been sufficiently new to the students to have an effect across student populations, teachers, and school settings. ${ }^{15}$

Of course our study has some limitations. We do not know how the teachers involved in the project affected changes in tolerance. Other research has suggested that an open and democratic classroom climate in which students feel free to express their opinions is related to the development of tolerance (Torney, Oppenheim \& Farnen, 1975). Students' perception of the teacher's credibility has also been noted as an important variable (Goldenson, 1978). Our understanding of how the curriculum was taught is based on the teachers' descriptions of their experiences, as well as student responses to open-ended questions. A more thorough study would include observations of the classes, with particular attention to the classroom climate.

The teachers in our studies were self-selected; their very willingness to try an experimental curriculum suggests an openness to different teaching materials and strategies. Most of the teachers were also quite experienced-three of the teachers had taught for more than fifteen years, while one had taught four years. In the hands of more traditional, less experienced teachers, the curriculum might have had different effects on students' levels of tolerance.

Still, the effectiveness of this curriculum has important implications for educating the citizens of a democratic society. Some empirical democratic theorists have cautioned against trusting ordinary citizens to make fundamental decisions about democratic rights (Berelson, Lazarsfeld, \& McPhee, 1954; Schumpeter, 1943). Rather, they argue that political elites, who possess the requisite understanding of how democratic norms and values ought to be applied, should make the difficult choices about democraticrights. Studies of tolerance generally show, as well, that so-called elites do perform with greater consistency when asked about concrete implementations of minority rights (e.g., Barnum

15 Student responses to an item on the posttest provide support for this conclusion. When asked to describe the curriculum on a five-point scale with 1 as "ideas new to me" and 5 as "same old stuff," only 4 percent of the students marked the box assigned a score of 5 and 11 percent the box assigned a score of 4 . 
\& Sullivan, 1989; McClosky, 1964; McClosky \& Brill, 1983; Nunn, Crockett, \& Williams, 1978; Prothro \& Grigg, 1960; Stouffer, 1955). 16

Our study's results provide a glimmer of hope. We believe that if civic education were to include a systematic examination of the role of dissent in a democratic society, young people might develop a commitment to protect civil liberties that would ultimately engender a more fully democratic citizenry. Our study suggests that if tolerance of diverse beliefs is an important democratic ideal, it may be possible to realize this ideal through challenging and creative curricula. We may be able to create the conditions for a democratic culture in which we need not fear the actions of an intolerant citizenry.

16 For some exceptions, see Gibson and Duch (1991), Shamir (1991) and Sniderman, Fletcher, Russell, \& Tetlock (1989). 


\begin{abstract}
APPENDIX
The curriculum Tolerance for Diversity of Beliefs consists of seven lessons which extend over a period of three to four weeks. Each lesson includes a set of guiding questions and learner objectives.

\section{Lesson 1: Victims of Intolerance}

What is intolerance? Who are the victims of intolerance?

Lesson 1 focuses on victims of intolerance. Students define tolerance as a group and then categorize a number of concrete situations in terms of the degree to which they are deserving of tolerance. In their journals, students record how important tolerance is to them on a scale of 1-10 and how important they think tolerance should be for the well-being of humanity. Students then divide into three groups; each group reads one case study-the Japanese-American internment during World War II, the Holocaust, or the Cultural Revolution in China. Groups role play the case studies for the entire class.
\end{abstract}

\title{
Lesson 2: Intolerance—From Whence It Comes
}

Why are individuals/groups intolerant?

Lesson 2 examines the roots of intolerance, helping students to explore conditions that create intolerance in people or groups. Students are asked to write in their journals about behaviors that test their tolerance, people/groups of which they are sometimes intolerant, and a situation in which they behaved in an intolerant manner. Volunteers share these instances with the class to see if any generalizations can be made. Students read a fictional account of a class bully to develop an understanding of the origins of intolerance. The "Bully Bulletin" provides information from psychological and sociological studies of bullies.

\section{Lesson 3: Basic Human Rights}

What are basic human rights? What is the relationship between rights, responsibilities and tolerance?

Lesson 3 considers the question of basic human rights, focusing on the balance between rights and responsibilities. Students list human rights and try to decide which of these they would term "basic." Working in groups, the students choose the three rights considered most important; they then compare the rights they selected with the rights protected by the constitutions of several nations. Next, students consider possible limitations to basic rights and how these rights are tied to responsibilities. Finally, students view a twenty-minute video, "I-Team Hate Mail," that focuses on the relationship between beliefs and actions and whether one is entitled to express one's beliefs if that action will hurt others. Elroy Stock, the main character in the video, wrote letters to people in racially or religiously "mixed" marriages telling them they were wrong. In their journals, students react to Stock's actions, and what they might do if confronted with someone with similar views. 


\section{Lesson 4: Case Studies}

How have issues of intolerance been addressed in the United States courts?

Lesson 4 examines national case studies. The first case involves high school students protesting the Vietnam War by wearing black armbands to school. When the school officials objected, the students sued, taking their case all the way to the Supreme Court. The second case involves the American Nazi Party's attempt to march in Skokie, Illinois, an area heavily populated by Jews who had escaped from Nazi Germany. Students simulate the cases, playing the parts of attomeys for each side and judges or justices.

\section{Lesson 5: International Rights and Responsibilities}

What international standards address issues of intolerance?

Lesson 5 extends the concept of tolerance to the intermational level. Students read the Universal Declaration of Human Rights, adopted by the United Nations in 1948, and compare it to the United States Bill of Rights. Students analyze the disparity between principles and practice in news articles, and suggest reasons for the disjuncture.

\section{Lesson 6: Belief and Believers}

Who are the people, past and present, who followed their consciences and acted on their beliefs?

Lesson 6 focuses on advocates for tolerance and victims of intolerance. Students receive: (1) a list of the names of people who have acted on their beliefs, even when it was dangerous for them to do so, and (2) a list that describes each person's relationship to freedom of expression. Students match the names to the descriptions by consulting reference materials in the school library. In addition, two students previously selected by the teacher role play a mock interview with Aryeh Neier to explore his beliefs about freedom of expression. Neier, a Jew, defended the Nazis' right to march in Skokie in his position as a leader of the American Civil Liberties Union.

\section{Lesson 7: Taking Action to Increase Understanding of Rights of Expression}

What actions can be taken to increase understanding of rights of expression?

The final section, Lesson 7, invites students to consider actions they might take to increase understanding of freedom of expression. First, students explore the rights and responsibilities they believe they should have in the classroom. Then, the students work in small groups to identify intolerance in their school, community, nation or world and offer suggestions as to actions they might take. One possibility introduced to them is that of forming an Amnesty International group at the school. To conclude the unit, students return to the exercise in Lesson 1 in which they were asked to rate the importance of tolerance to themselves and to the well-being of humanity. They complete the ratings again, and discuss any changes in their views. 


\section{REFERENCES}

Adams, G. R. (1985). Identity and political socialization. In A. S. Waterman (Ed.), Identity in adolescence: Processes and contents (pp. 61-77). San Francisco: Jossey Bass.

Adelson, J. (1971). The political imagination of the young adolescent. Developmental Psychology, 1 , 1031-1051.

Altemeyer, B. (1988). Enemies of freedom. San Francisco: Jossey-Bass.

Avery, P. (1988). Political tolerance among adolescents. Theory and Research in Social Education, 16, 183-201.

Avery, P., Bird, K., Healy, S., Sullivan, J., L. \& Thalhammer, K. (1991, April). Political tolerance among adolescents: The potential of curricular socialization. Paper delivered at the meeting of the Midwest Political Science Association, Chicago, IL.

Barnum, D., \& Sullivan, J. L. (1989). Attitudinal tolerance in the United Kingdom: A comparison on members of Parliament with the mass public. British Journal of Political Science, 19, 136-146.

Berelson, B., Lazarsfeld, P. F., \& McPhee, W. (1954). Voting. Chicago: University of Chicago Press.

Bobo, L., \& Licari, F. C. (1989). Education and political tolerance. Public Opinion Quarterly, 53, 285308.

Breslin, A. (1982). Tolerance and moral reasoning among adolescents in Ireland. Journal of Moral Education, 11, 112-127.

Carroll, J. D., Broadnex, W. D., Contreras, G. , Mann, T. E., Orenstein, N. J., \& Steihm, J. (1987). We the people: A review of U.S. government, and civics textbooks. Washington, DC: People for the American Way.

Corbett, M. (1991). American public opinion. New York: Longman.

Dennis, J., Lindberg, L., McCrone, D., \& Stiefbold, R. (1968). Political socialization to democratic orientations in four western systems. Comparative Political Studies, 1, 71-101.

Denver, D., \& Hands, G. (1990). Does studying politics make a difference? The political knowledge, attitudes, and perceptions of school students. British Journal of Political Science, 20, 263-288.

Ehman, L. H. (1980). The American school in the political socialization process. Review of Educational Research, 50(1), 99-119.

Eyler, J. (1980). Citizenship education for conflict: An empirical assessment of the relationship between principled thinking and tolerance for conflict and diversity. Theory and Research in Social Education, 8 (2), 11-26.

Famen, R., \& German, D. B. (1972). Youth, politics, and education. In B. G. Massialas (Ed.), Political youth, traditional schools, (pp. 161-177). Englewood Cliffs, NJ: Prentice-Hall.

Gallatin, J. E. (1985). Democracy's children. Ann Arbor, MI: Quode Publishing Company. 
Gibson, J. L. (1988). Political intolerance and political repression during the McCarthy red scare. American Political Science Review, 82, 511-529.

Gibson, J. L. (1989). The structure of attitudinal tolerance in the United States. British Journal of Political Science, 19, 562-570.

Gibson, J. L., \& Duch, R. M. (1991). Elitist theory and political tolerance in western Europe. Unpublished manuscript.

Goldenson, D. R. (1978). An altemative view about the role of the secondary school in political socialization: A field-experimental study of the development of civil liberties attitudes. Theory and Research in Social Education, 6, 44-72.

Goldstein, R. J. (1987). The United States. In J. Donnelly \& R. E. Howard (Eds.), International Handbook of Human Rights (pp. 429-456). New York: Greenwood Press.

Grossman, D. L. (1974). Educational climates and attitudes toward dissent: A study of political socialization of conflict norms in adolescents. Paper presented at the Annual Meeting of the American Educational Research Association. (ERIC Document Reproduction Service No. ED 090 127)

Hepburn, M. A. (1980). How do we know what they know? Teaching Political Science, 7 (4), 425-438.

Jennings, M. K., \& Niemi, R. G. (1981). Generations and politics. Princeton, NJ: Princeton University Press.

Jones, R. S. (1980). Democratic values and preadult virtues. Youth and Society, 12, 189-220.

Katz, E. (1985). Federalism in secondary school American history and government textbooks. In S.L. Schecter (Ed.), Teaching about American federal democracy (pp. 91-98). Philadelphia, PA: Temple University Center for the Study of Federalism.

Langton, K. P., \& Jennings, M. K. (1968). Political socialization and the high school civics curriculum in the United States. American Political Science Review, 62, 852-867.

McClosky, H. (1964). Consensus and ideology in American politics. American Political Science Review, $58,361-382$.

McClosky, H., \& Brill, A. (1983). The dimensions of tolerance. New York: Russell Sage.

McClosky, H., \& Zaller, J. (1984). The American ethos. Cambridge, MA: Harvard University Press.

Miller, S. D., \& Sears, D. O. (1986). Stability and change in social tolerance: A test of the persistence hypothesis. American Journal of Political Science, 30, 214-236.

Montero, D. (1975). Support for civil liberties among a cohort of high school graduates and college students. Journal of Social Issues, 31, 123-135.

NAEP (National Assessment of Educational Programs). (1990). The civics report card. Washington, DC: U.S. Department of Education.

NAEP (National Assessment of Educational Progress). (1980). Citizenship and social studies objectives: 1981-82. Denver CO: Education Commission of the States. (ERIC Document Reproduction Service No. ED 186330 ) 
NAEP (National Assessment of Educational Progress). (1978). Changes in political knowledge and attitudes, 1968-76. Denver, CO: Education Commission of the States. (ERIC Document Reproduction Service No. ED 166 123)

NCSS (National Council of the Social Studies) Task Force on Scope and Sequence. (1989). In search of a scope and sequence for social studies. Social Education, 53, 376-385.

Nielson, H. D. (1977). Tolerating political dissent. Stockholm: Almqvist \& Wiksell Intemational.

Nunn, C. A., Crockett, H. J., \& Williams, J. A. (1978). Tolerance for nonconformity. San Francisco: Jossey Bass.

Owen, D., \& Dennis, J. (1987). Preadult development of political tolerance. Political Psychology, 8 , 547-561.

Patrick, J.J. (1991). Teaching the Bill of Rights in secondary schools. The Social Studies, 82, 227-31.

Patrick, J. J., \& Hawke, S. D. (1982). Curriculum materials. In I. Morrissett (Ed.), Social Studies in the 1980s: A Report of Project SPAN (pp. 39-50). Arlington, VA: Association for Supervision and Curriculum Development.

Patrick, J. J., \& Hoge, J. D. (1991). Teaching government, civics, and law. In J. P. Shaver (Ed.), Handbook of research on social studies teaching and learning (pp. 427-436). New York: MacMillan.

Patterson, J. W. (1979). Moral development and political thinking: The case of freedom of speech. Western Political Quarterly, 32, 7-20.

Prothro, J., \& Grigg, C. (1960). Fundamental principles of democracy: Bases of agreement and disagreement. Journal of Politics, 22, 276-294.

Remy, R. C. (1981). Treatment of the constitution in civics and govemment textbooks. In H. D. Mehlinger (Ed.), Teaching about the constitution in American secondary schools (pp. 107128). Washington, DC: Project ' 87 of the American Historical Association and the American Political Science Association.

Rokeach, M. (1960). The open and closed mind. New York: Basic Books.

Rosenberg, M. (1965). Society and the adolescent self-image. Princeton: Princeton University Press.

Schumpeter, J. A. (1943). Capitalism, socialism, and democracy. London: Allen and Unwin.

Shamir, M. (1991). Political intolerance among masses and elites in Israel. Journal of Politics, 53, 1018-1043.

Sigel, R., \& Hoskin, M. (1981). The political involvement of adolescents. New Brunswick, NJ: Rutgers University Press.

Sniderman, P. (1975). Personality and democratic politics. Berkeley, CA: University of California Press.

Sniderman, P.M., Fletcher, J.F., Russell, P.H., \& Tetlock, P.E. (1989, December). The fallacy of democratic elitism: Elite competition and commitment to civil liberties. Paper delivered at the meeting of the American Political Science Association, Atlanta, GA. 
Sniderman, P. M., Tetlock, P. E., Glaser, J. M., Green, P., \& Hout, M. (1989). Principled tolerance and the American mass public. British Journal of Political Science, 19, 25-45.

Stouffer, S. (1955). Communism, conformity, and civil liberties. New York: Doubleday.

Sullivan, J. L., Marcus, G., Piereson, J., \& Feldman, S. (1978-1979). The development of political tolerance: The impact of social class, personality, and cognition. International Journal of Political Education, 2, 115-139.

Sullivan, J. L., Piereson, J. \& Marcus, G. E. (1982). Political tolerance and American democracy. Chicago, IL:University of Chicago Press.

Sullivan, J. L., Shamir, M., Walsh, P. \&, Roberts, N. S. (1985). Political tolerance in context: Support for unpopular minorities in Israel, New Zealand and the United States. Boulder, CO: Westview Press.

Tomey, J.V., Oppenheim, A.N., \& Farnen, R. F. (1975). Civic education in ten countries. New York: John Wiley \& Sons.

Tomey-Purta, J. (1990). Youth in relation to social institutions. In S. Feldman \& G. Elliott (Eds.), At the threshold: The developing adolescent, (pp. 457-477). Cambridge, MA: Harvard University Press.

Wagner, J. (1986). Political tolerance and stages of moral development: A conceptual and empirical alternative. Political Behavior, 8, 45-80.

Zellman, G. L. (1975). Antidemocratic beliefs: A survey and some explanations. Journal of Social Issues, 31, 31-53.

Zellman, G. L., \& Sears, D. O. (1971). Childhood origins of tolerance for dissent. Journal of Social Issues, 27, 109-135. 